Historic, Archive Document

Do not assume content reflects current scientific knowledge, policies, or practices. 



\section{Flower Seed}

SPCelatiles:

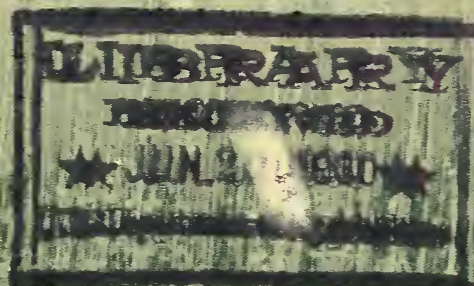

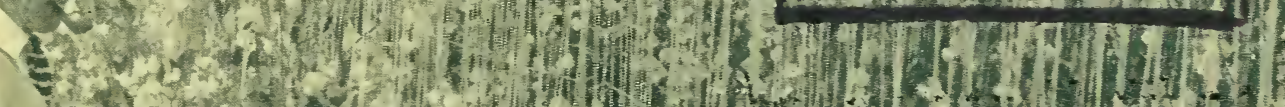
50 (1)

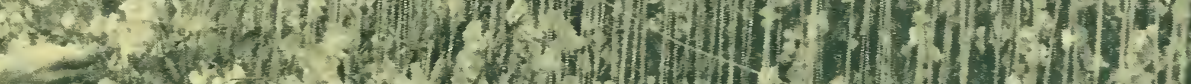

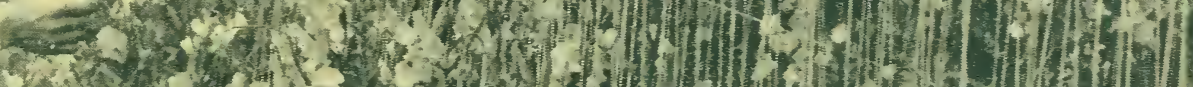

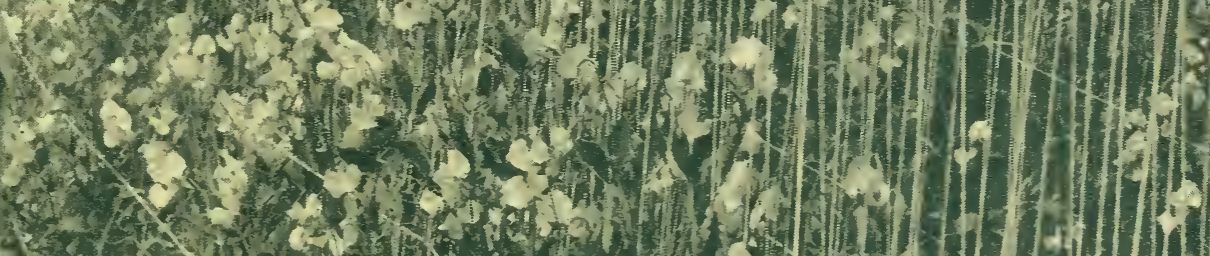

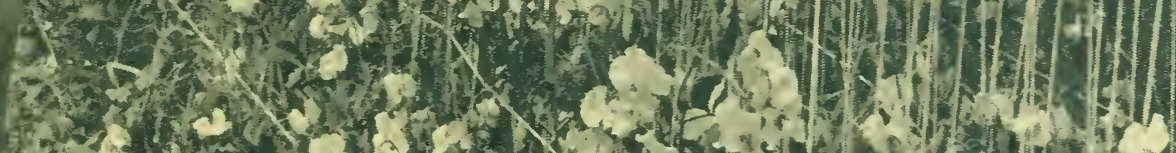

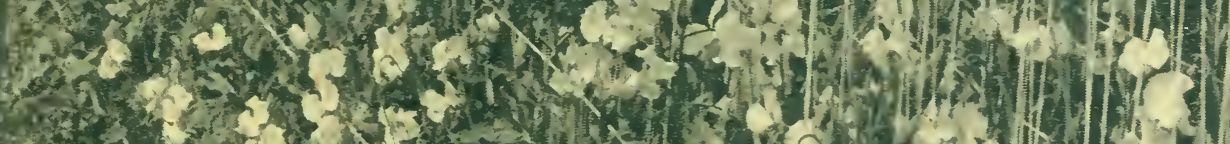

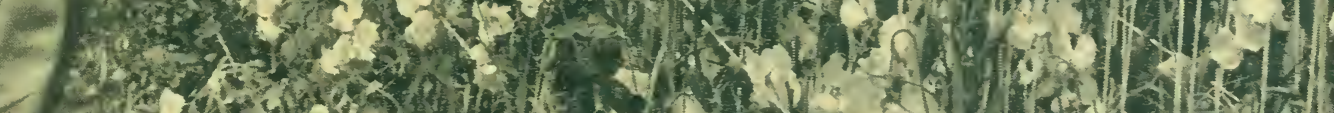

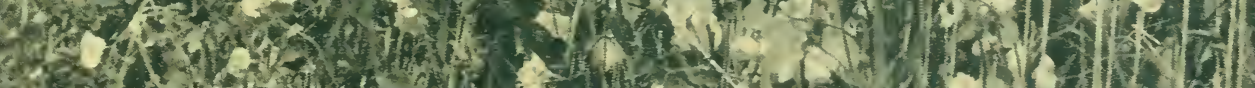

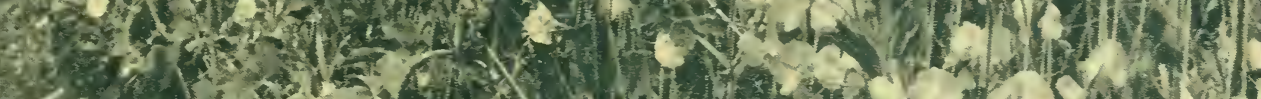

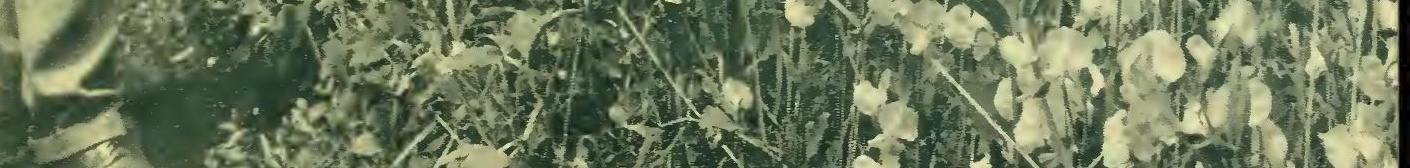

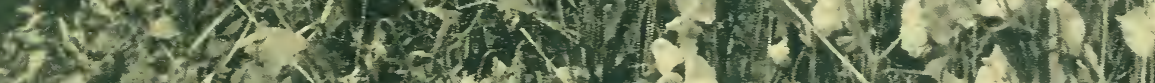

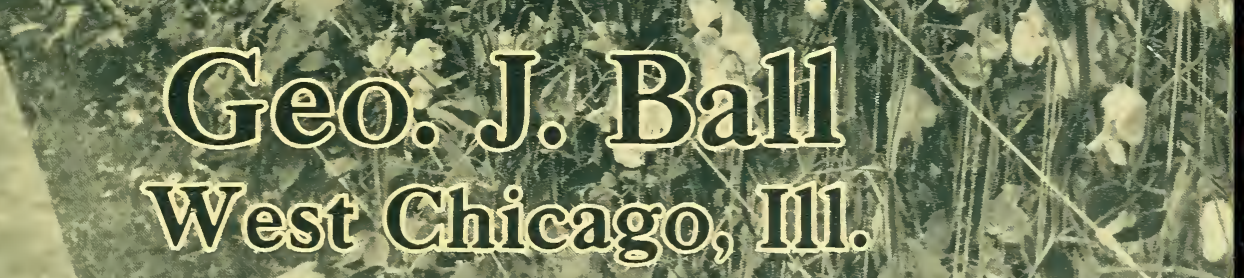
$<2+1,12$

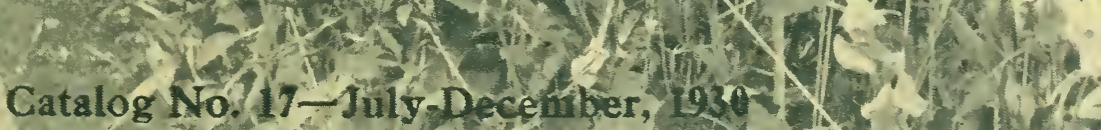




\section{Flower Seed Specialties}

\section{For Fall 1930}

UR seed business has been developed during the past ten years to a list of 8500 active customers that is being added to daily. One of the principal reasons for this growth is that we are thoroughly familiar, through being market growers, with the various specialties offered in this catalogue. 'This experience gives us first-hand information as to the value of varieties and growers requirements. We have your point of view and we try to accurately describe what we are offering. The growth of our seed business proves this a good foundation to build a business on.

This catalogue is our only salesman. It is not intended to persuade you to buy what you do not want, nor should not have; neither will it try to oversell you.

Please bear in mind that our seed specialties cannot be bought from jobbers, because we do not sell to them except in our packets. Avoid errors on this point by ordering direct from this catalogue.

\section{OUR SERVICE}

We realize that our business depends on your success with our seed. It follows that we should not only supply you with the best possible strains of seed, but be of what service we can in your growing problems. Please feel free to write us. We issue the following circulars that cover in considerable detail the subjects treated: Early or Winter Peas; Late or Summer Peas; Stocks; Asters; Zinnias, and Miscellaneous Crops. Two circulars are issued on Calendula, one by ourselves, from the stand. point of a market grower, and another by Fritz Bahr, that deals with this crop from the retail grower's viewpoint. We shall gladly send you gratis either or both.

"BETTER SWEET PEAS," By Geo. J. Ball. (Florists' Publishing Co., Chicago.) A cloth-bound book of 210 pages freely illustrated and covering in detail the growing of early or winter-flowering peas under glass. A chapter is devoted to the late or summer-flowering type, also one to the miscellaneous crops that are handled to advantage by sweet pea growers. The author's system of steam sterilizing soil is described and illustrated in detail. A chapter is devoted to the history of sweet peas, particularly the origin of the early or winter type that has become such a popular cut flower crop. This can be supplied by us at the publisher's price, $\$ 1.75$ postpaid.

\section{DISCOUNTS}

All orders of $\$ 3.00$ or over are subject to a discount of $5 \%$ when remittance is enclosed with order. On all open accounts of $\$ 10.00$ or over we allow a discount of $5 \%$ if paid within ten days of date of invoice. After sixty days all bills are subject to sight draft unless arrangements are made with us for extension.

To save delay in filling your order, please observe the following: If you are unknown to us or have no commercial rating, cash must be enclosed with order unless satisfactory Chicago trade reference is submitted.

\section{SMALL ORDERS}

We gladly welcome and assure the same liberal and prompt attention given to larger ones. In return we suggest that cash be enclosed to cover the proportionately greater cost of handling. All prices are based to cover postage and insurance. 


\section{Flower seed Stegogahties For Florists}

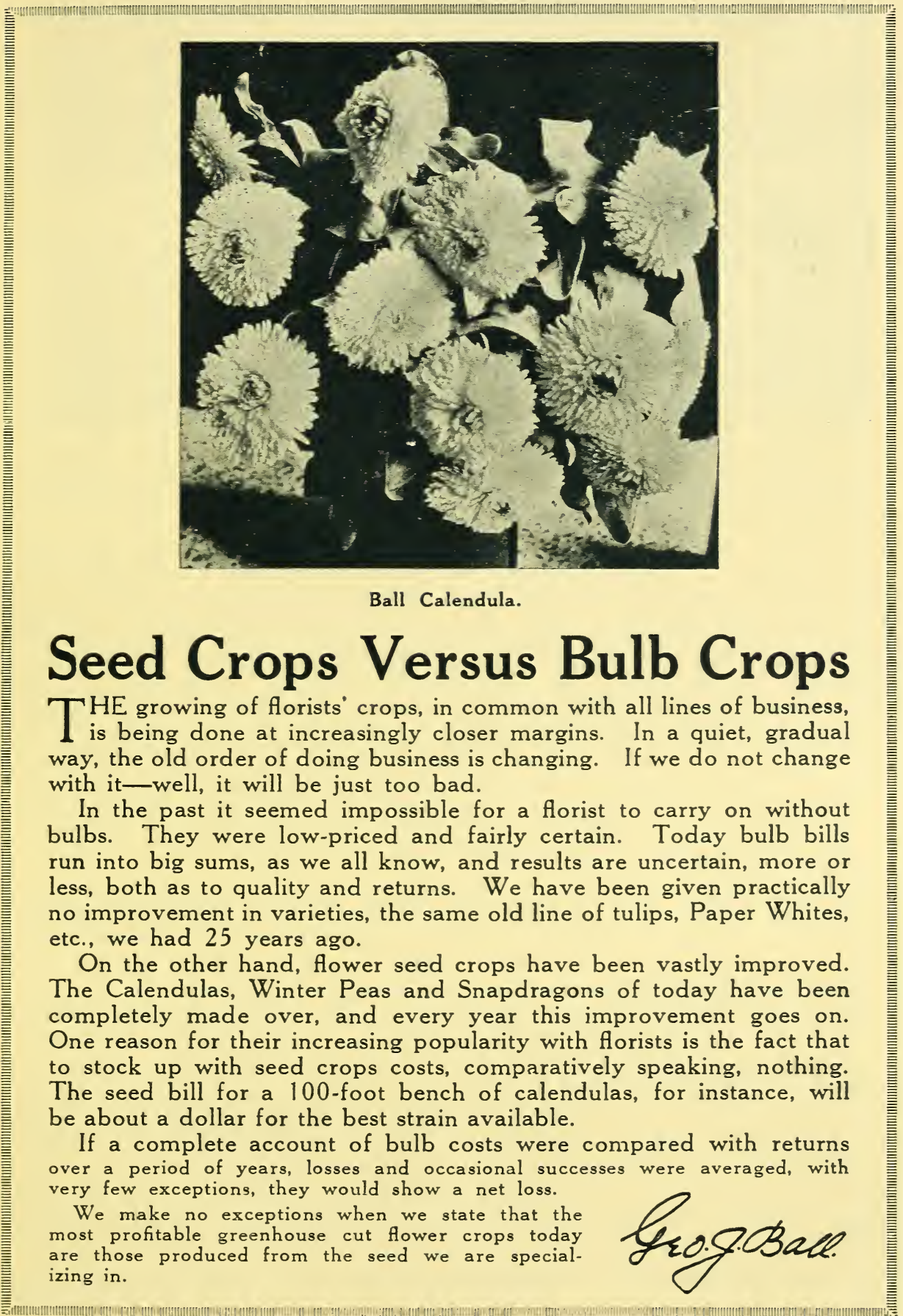



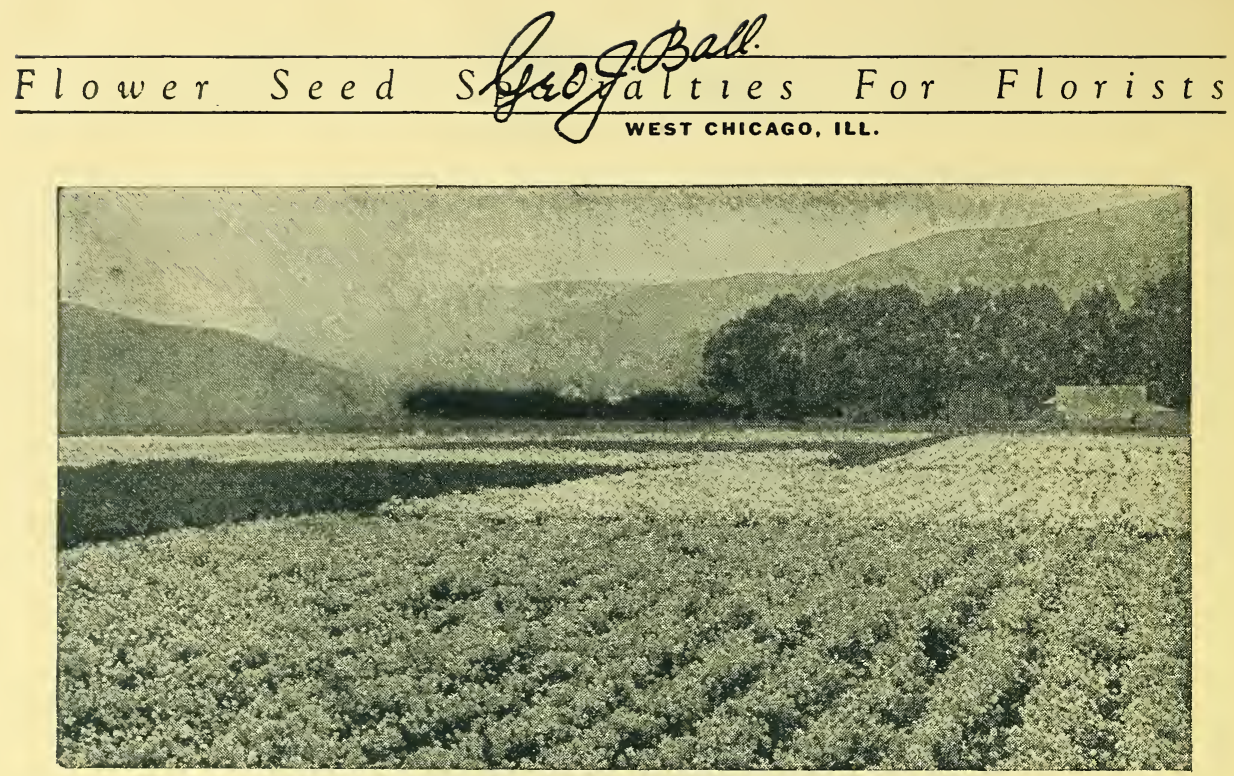

A seed field of our Early or Winter Flowering Sweet Peas in California. Our Ball Rose in the foreground, White Harmony in the back, and our Ball Orange on the left. This favored valley produces the best matured sweet pea seed in the world. These fields, as well as the crops under glass pictured on cover page, are under our close personal supervision and we are very sure that more carefully rogued seed cannot be had at any price or from any source.

\section{Growing Winter Peas}

W/TH clean, well drained soil and a light, well ventilated house, no florist crop is Weasier or more profitable to grow than "peas." "Whether you retail your product or sell it through a commission house, one of the important points is the selection of suitable colors. Clear, bright shades of pink and lavender head this list, and any market wants some white, blue and orange. The variety that attracted most attention at recent flower shows was the chocolate striped Harlequin. Little of this will sell, but as an attraction it is valuable. The striped effect in the variety Aurora sells fairly well as a Spring novelty color. We call special attention to a few of the season's novelties in early peas. We list no new varieties without a careful trial in our greenhouses, for it frequently happens that a variety will be distinctive in the open but worthless under glass.

THE following new varieties have been carefully tested by us in our greenhouses, and we find 1 them a distinct advance in their respective colors. Descriptions are as we find them. They are the productions of the Ferry-Morse Seed Co., and all three have received high awards wherever exhibited. Please note that these varieties are moderately priced, especially when the years spent in their production is considered.

\section{EARLY PAL}

This is large-flowering; a rich shade of rose-crimson, produced on extra long stems. This combination of colors is an original and most arresting one. Fine through the winter months, but at its best during the spring. $\quad$ Trade packet, 50 c; $1 / 4$ oz., 75 c; $1 / 2$ oz., $\$ 1.25 ; 1$ oz., $\$ 2.00 ; 4$ oz., $\$ 7.00$.

EARLY VOGUE This we find an improvement in lavenders, having a distinct bluish tone that enriches the general effect. We find a good lavender a most important market color.

Trade packet, 50c; $1 / 4$ oz., 75c; $1 / 2$ oz., $\$ 1.25 ; 1$ oz., $\$ 2.00 ; 4$ oz., $\$ 7.00$.

EARLY FANDANGO This is an extra large, bright, dark rose duplex, about the shade of the late-flowering Rosabelle. Under ordinary greenhouse conditions it produces extra long stems, with an average of three flowers to a stem and with usually two of them well doubled. Not as strong in growth as is the regular early type, but we find it amply so under favorable conditions. Bunched effect is very fine, and where the early type does well outdoors, this new early duplex will be highly attractive. Trade packet, $50 \mathrm{c} ; 1 / 4 \mathrm{oz} ., \$ 1.00 ; 1 / 2 \mathrm{oz} ., \$ 1.50 ; 1 \mathrm{oz} ., \$ 2.50 ; 4 \mathrm{oz}$., $\$ 8.00$.

HOPF This is a Wm. Macdonald Seed Co. introduction that we have had on trial - We find it a large, black-seeded white, freely produced on long, graceful stems. We find its outstanding merit to be its very free-flowering habit and clear, paper-white color.

Trade packet, $50 \mathrm{c} ; 1 / 4 \mathrm{oz}$., $75 \mathrm{c} ; 1 / 2 \mathrm{oz} ., \$ 1.25 ; 1$ oz.. $\$ 2.00 ; 4 \mathrm{oz} ., \$ 7.00$. 


\section{Flower seed Sfegogalties For Florists}

\section{Outstanding Winter Peas $\underset{1930-31}{\text { For }}$}

BALL ROSE "The finest winter sweet pea." A sparkling, deep BALL ROSE rose color, with long, graceful stems and free-fowering habit. Unlike the Zvolanek's Rose shade of pink, Ball Rose holds its deep color through the dark months. When compared with Ball Rose, all other shades of rose seem faded and dull.

$1 / 2$ oz., 35c; 1 oz., 60 c; 4 oz., $\$ 2.00 ; 8$ oz., $\$ 3.75 ; 1$ lb., $\$ 7 ; 5$ lbs., $\$ 30$. BALL ORANGE A glowing, clear, deep, early-flowering B orange. It is without a trace of dark or uneven shading. Instead of fading under a strong sun, as do most orange varieties, the color of Ball Orange actually becomes more intense. Awarded the S. A. F. gold medal.

$1 / 2$ oz., 60c; 1 oz., $\$ 1.00 ; 4$ oz., $\$ 3.00 ; 8$ oz., $\$ 5.50 ; 1$ lb., $\$ 10 ; 5$ lbs., $\$ 40$. BALL'S ROSE QUEEN This is a long-stemmed, fairly a cross between Zvolanek's Rose and Rose Queen, combining the good points of both. Because of its fine stem and vigorous growth, we find this the choicest of the regular rose colors.

$1 / 2$ oz., 30c; 1 oz., 50c; 4 oz., \$1.75; 8 oz., \$3.00; 1 lb., \$6; 5 lbs., \$25. WHITE HARMONY The very best in early-fowering

It is also black-seeded, It is also black seeded, easy to germinate. From every point of view, this should be preferred to a white-seeded white, that is frequently lost through rot. $1 / 2$ oz., 60 c; 1 oz., $\$ 1.00 ; 4$ oz., $\$ 3.00 ; 8$ oz., $\$ 5.50 ; 1$ lb., $\$ 10 ; 5$ lbs., $\$ 40$. SUNRAY A brilliant, even, soft cerise that fairly glows under artifree-flowering variety. With us the color is at its best in the Spring.

$1 / 2$ oz., 60c; 1 oz., $\$ 1.00 ; 4$ oz., $\$ 3.75 ; 8$ oz., \$6.75; 1 lb., $\$ 12.50$.

GIANT ROSE

A finely named variety, for it is of the largest size, and strongly inclined to produce four flowers on strong stems. A clear, rose-colored flower with a vigorous growth. $1 / 2$ oz., 30c; 1 oz., 50c; 4 oz., $\$ 1.75 ; 1 / 2$ lb., $\$ 3.50 ; 1$ lb., $\$ 7 ; 5$ lbs., $\$ 30$. MAJESTIC ROSE In growth, size of flowers and stems, we with flowers a shade deeper in color.

$$
1 / 4 \text { oz., 75c; 1/2 oz., } \$ 1.25 ; 1 \text { oz., } \$ 2.00 ; 4 \text { oz.. } \$ 7.00 \text {. }
$$

SPRINGSONG Extra large flowers of a highly attractive shade $1 / 2$ oz., 35c; 1 oz., 60c; 4 oz., \$2.00; 1/2 lb., \$3.75; 1 lb., $\$ 7.00$.

MRS. HERBERT HOOVER We find this to be a distractive blue of fine size and borne on long graceful stems.

Pkt., 25c; $1 / 2$ oz., 75c; 1 oz., $\$ 1.50 ; 4$ oz., $\$ 4.50 ; 1 / 2$ lb., $\$ 8.00 ; 1$ lb., $\$ 15$. BALL'S BLUE A large, clear, even blue of good size, fine stiff stems. $1 / 2$ oz., 30c; 1 oz., 50c; 4 oz., $\$ 1.75 ; 1 / 2$ lb., $\$ 3.25 ; 1$ lb., $\$ 6.00$. 


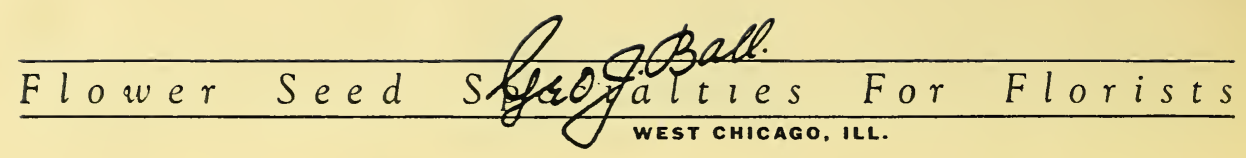

\section{"All the Best" Standard Winter Peas}

VYE fully appreciate the value and practical importance of our list of W standard varieties. We feel sure that no inferior kind will be found among the following.

PINK SHADES

B COLUMBIA. Blanche Ferry pink and white combination $1 / 2$ oz.

B BALL ROSE and BALL'S ROSE QUEEN. See page 3.

ZVOLANEK'S ROSE. Large, well colored rose ...........................................

JEANNE MAMITSCH. A fine, extra long-stemmed rose

FAIR MAID. Blush or light pink

.35

LOUISE GUDE. A good free rose.

.30

PINK CHEROKEE. Bright cream-pink....

SUPERIOR PINK. Deep rose-pink.

MRS. CALVIN COOLIDGE. Salmonpink suffused orange

.30

.35

.35

\section{LAVENDER}

HARMONY. Extra large, clear lavender, with fine growth and long stems..

LAVENDER KING. Not quite so large as Harmony, but free-flowering.

WWEET LAVENDER. A good, even lavender; does not grow as tall as others..

.30

$.50 \quad 1.50$

5.00

\section{BLUE}

B BALL'S BLUE. See page 3.

BLUE BIRD. Large long-stemmed......... .30

BLUE JACKET. Dark or navy-blue......

SILVER BLUE. Long lavender-blue....

EARLY INDIGO BLUE. A fine, dark blue bicolor

MRS. HARDING. The Harding blue...

.30

WHITE HARMONY. See page 3.

SNOWSTORM. The standard clear whiteseeded white

WHITE STAR. Free-flowering blackseeded white

(B) BALL ORANGE. See page 3.

BURPEE ORANGE. Rich light orange

MRS. KERR. Rich, even salmon.............

ELDORADO. Fine Salmon-orange......... 


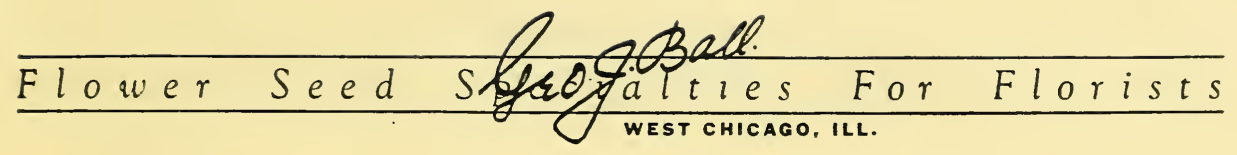

SCARLET and CERISE

EARLY BRIGHT LIGHT. Orangescarlet, a vivid color. 1/2 oz. $\quad$ I oz. 4 oz.

$1 \mathrm{lb}$.

GRENADIER. A brilliant poppy-scarlet

FLAMINGO. An extra long-stemmed

orange and salmon .........................
GORGEOUS. Large, long-stemmed salmon-cerise

$\$ 0.30$

$\begin{array}{rrrr}.35 & \$ 0.50 & \$ 1.60 & \$ 5.50 \\ .30 & .60 & 1.75 & 6.00 \\ & .50 & 1.60 & \mathbf{5 . 5 0} \\ .30 & .50 & 1.50 & \mathbf{5 . 0 0} \\ .30 & .50 & 1.60 & \mathbf{5 . 5 0}\end{array}$

GLITTERS. Bright scarlet-cerise

.30

5.50

\section{MISCELLANEOUS COLORS}

CHEVALIER. Large, long deep rose..... striped. Bunched effect very rich

HARLEQUIN. Striped and flaked deep chocolate; very fine novelty color..... MEADOW LARK. The best clear cream YARRAWA. Rose and cream.............. "ALL THE BEST" MIXTURE.

$\begin{array}{llll}.30 & .50 & 1.60 & \mathbf{5 . 5 0} \\ .30 & .50 & 1.50 & \mathbf{5 . 0 0} \\ .30 & .50 & 1.50 & \mathbf{5 . 0 0} \\ .30 & .50 & \mathbf{1 . 5 0} & \mathbf{5 . 0 0}\end{array}$

\section{Late, or Summer Flowering Peas}

I N northern border states and Canada, where summers are comparatively cool, late peas 1 can be sown outdoors early and will flower freely throughout the season. In the latitude of Chicago, they must be started early and planted as well established plants about ApriI 15. Further south, they are sown late in the fall, and after they are well through the ground, they can be carried through a considerable freeze by covering with any loose material that will prevent too much thawing and freezing. Nothing is more valuable than a covering of snow. With the early-flowering peas planted after Mums, or later, we use good colors of this late type, planting about eight or ten inches apart in the row. The late kind does not grow up with the earlies, but branch freely at the base until the earlies are exhausted; then the late ones overgrow them and produce heavily with us, through June. The varieties marked * are the choicest cut flower colors.

* PINKIE. The finest commercial rose-pink

* HEBE. The standard rose-pink

HERCULES. A very good rose-pink.

HAWLMARK PINK. Rose-pink shaded salmon

ELFRIDA PEARSON. Clear, light pink.

* MISS CALIFORNIA. Very fine salmon-rose pink

YOUTH. Light Picotee pink

* MAGNET. The finest rich cream-pink

MRS. CUTHBERTSON. Pink and white bicolor

SUPREME. Soft delicate pink

*HERO. A large rich cerise.

MARY PICKFORD. The finest cream or salmon-pink

*ONSTANCE HINTON. The best black-seeded white

EDNA MAY IMPROVED. Fine, large white-seeded white.

* AVALANCHE. Finest white-seeded white

*POWERSCOURT. Finest lilac-lavender.

* AUSTIN FREDERICK IMPROVED. Large rosy lavender. extra strong growth

HAWLMARK LAVENDER. Fine light lavender

* BLUE BIRD. The finest clear blue

MRS. TOM JONES. A very good blue,

COMMANDER GODSALL. Deep violet-blue

CRIMSON KING. Sunproof crimson...........

ROYAL SCOT. Sunproof orange-scarlet

* CAMPFIRE. Sunproof deep scarlet....

ROYAL PURPLE. Large rich purple.

WARRIOR. Deep bronze-maroon.

MATCHLESS. Clear deep cream

"ALLEEN. LARge rich carmine... Of the choicest colors most wanted..

\begin{tabular}{|c|c|c|}
\hline I/2 OZ. & $1 \mathrm{oz}$. & $1 \mathrm{lb}$. \\
\hline$\$ 0.20$ & & \\
\hline .15 & .25 & 2.25 \\
\hline .10 & .20 & 2.00 \\
\hline .15 & .25 & 2.25 \\
\hline .10 & .20 & 2.00 \\
\hline .15 & .25 & 2.25 \\
\hline .10 & .20 & 2.00 \\
\hline .20 & .30 & 2.75 \\
\hline .10 & .20 & 2.00 \\
\hline .15 & .25 & 2.50 \\
\hline .20 & .30 & 3.00 \\
\hline .15 & .25 & 2.50 \\
\hline .15 & .25 & 2.25 \\
\hline .15 & .25 & 2.25 \\
\hline .15 & .25 & 2.50 \\
\hline .10 & .20 & 2.00 \\
\hline .10 & .20 & 2.00 \\
\hline .15 & .25 & 2.25 \\
\hline 15 & .25 & 2.25 \\
\hline .10 & .20 & 2.00 \\
\hline .10 & .20 & 2.00 \\
\hline .10 & .20 & 2.00 \\
\hline .10 & .20 & 2.00 \\
\hline .15 & .25 & 2.50 \\
\hline .10 & .20 & 2.00 \\
\hline .10 & .20 & 2.00 \\
\hline .15 & .25 & 2.75 \\
\hline .15 & .25 & 2.50 \\
\hline .10 & .20 & 1.80 \\
\hline
\end{tabular}

NOTE: Any one of the above varieties in $5-1$. lots at a $20 \%$ discount from 1 . prices. We also supply $1 / 21 b$. at 1 b. rates on above late-flowering varieties. 


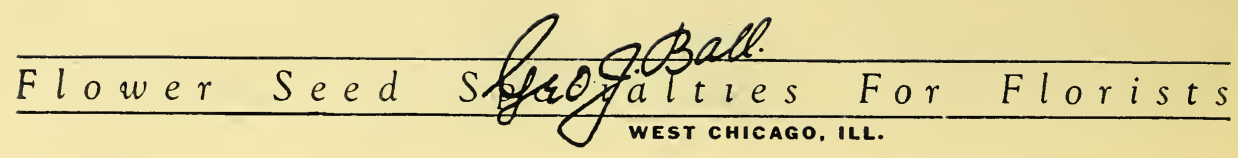

\section{Fine Stocks for Cut Flowers}

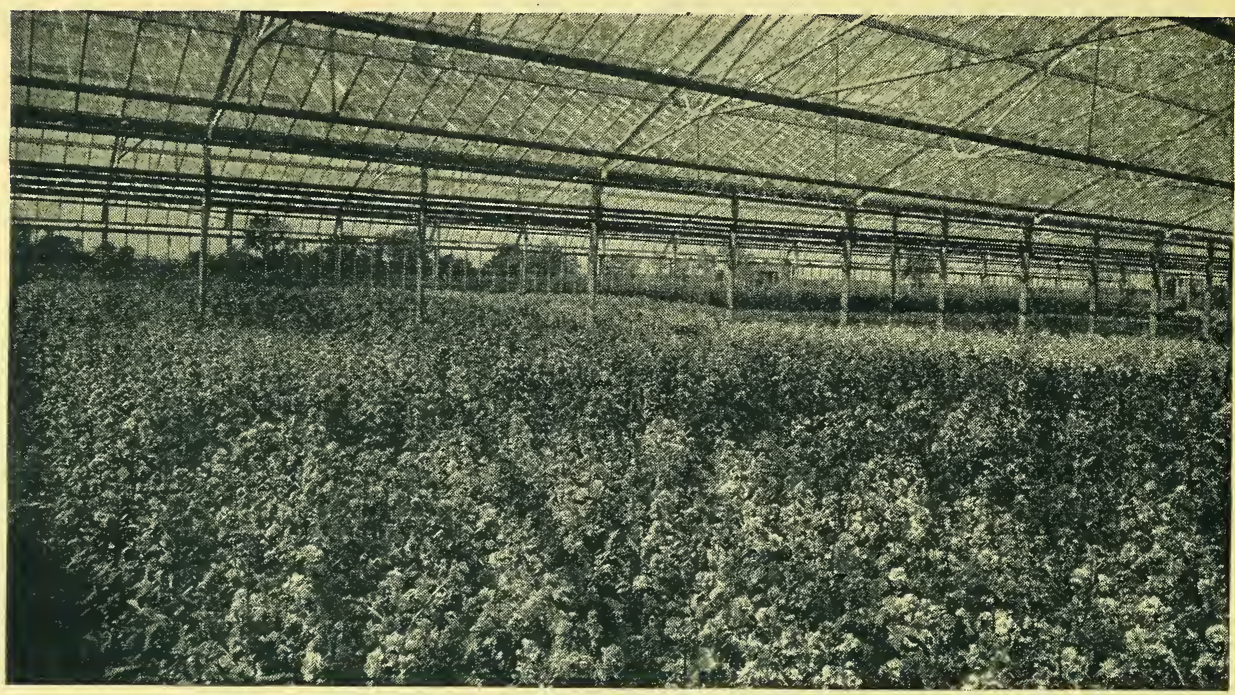

12,000 square feet of stocks grown on single stem or close planting method at Ball Gardens, West Chicago, Ill. The seed was sown February 1 in flats, transplanted March 10 in rows across the beds, 7 inches between the rows and 3 inches in the row. The photo was taken June 2. A few of the earliest were cut out for Mothers' day. With a slightly higher temperature, more would have been ready for this occasion. The soil used was fresh for a crop of peas that preceded the stocks. Old soil tends to produce the black stem rot this plant is subject to. One set of wire and string supports was used, but with a heavy growth this is not always enough.

RECAUSE of their fine, long stems, good percentage of doubles, and splendid range of colors, our American strains of stocks are rapidly becoming one of the leading cut flower specialties. When we add to their good points the fact that they are in flower in three months from planting of seedlings, we realize their value to cut flower growers.

As extensive growers of stocks for cut flowers, we appreciate the importance of strains that produce a good percentage of double flowers. We find the number of double ones is increased in our close planting, single stem method of growing because the singles are inclined to be the weakest and are therefore overgrown by the stronger doubles. This suggests the removal of the weakest seedlings.

We issue a circular describing in detail our method of growing stocks. It deals with this crop from a practical grower's standpoint. Should you not be familiar with the handling of this crop, it might be of service to you. We gladly send it gratis on request. 


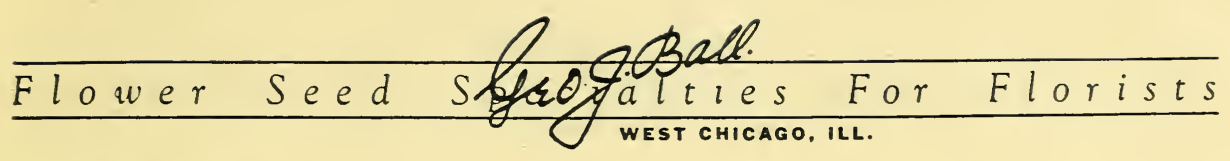

\section{The Choicest American Stocks}

THE following list is made up from extensive trials we conduct annually to determine 1 "All the best and nothing else." The Ten Weeks group are of compact growth and suitable only for bedding or pot plants. The varieties we find to be the most suitable market colors and grow in quantity are starred *.

\section{IMPROVED BISMARCKS}

A trifle earlier than the Nice or Perpetuals and not inclined to branch so freely, making them more suitable for our close planting method of growing. Cenerally considered the most valuable group of stocks for cut flowers.

* ROSE. Fine standard color.

*WHITE. Early clear white.

FLESH. Delicate shade of pink.

*LILAC. Lilac la vender.

*LAVENDER. Fine standard color.

*CHAMOIS. A choice market color.

*GOLDEN BALL. Clear ivory yellow.

ROYAL PURPLE. Rich deep purpie.

APPLE BLOSSOM. A choice light pink.

ANTIQUE COPPER. A fine copper-red.

GOLDEN ROSE. Light golden rose.

\begin{tabular}{llrrrrr} 
Prices on all the above separate colors & $1 / 3$ oz. & $\mathrm{T} / 4 \mathrm{oz}$. & $\mathrm{I} / 2 \mathrm{oz}$. & $1 \mathrm{oz}$. & $2 \mathrm{oz}$ \\
\hline BISMARCK MIXED, all colors & $\$ \ldots \ldots$ & $\$ 0.50$ & $\$ 1.00$ & $\$ 1.75$ & $\$ 3.00$ & $\$ 5.50$ \\
\hline
\end{tabular}

\section{PERPETUAL BRANCHING (Giant Perfection)}

A valuable group that produces fine, long stems and is of strong branching habit.

${ }^{*}$ ROSE. A clear even shade.

SAPPHIRE. Violet or dark lavender.

* MAY QUEEN. La vender or pale blue.

SNOWDRIFT. Fine clear white.

PRINCESS ALICE. Early white.

LA FRANCE. Blush, nearly white.

*HEATHAM BEAUTY. Terra cotta rose, very fine.

*EMPRESS AUGUSTA VICTORIA. Silver-lilac and very fine.

BRILLIANT. Blood-red, not a standard market color.

PERPETUAL BRANCHING MIXED. All colors.

\section{BEAUTY OF NICE}

For long stems and branching habit this is a fine group and includes some of our choicest kinds.

*MONT BLANC. Clear, extra early white.

ALMOND BLOSSOM. White tinged rose.

MONTE CARLO. Rich canary-yellow.

AURORA. Golden buff, fine.

BELLE DE NAPLES. Rich old rose.

SALMON KING. Strong salmon-rose.

BEAUTY OF NICE. Flesh-pink.

COTE DE AZURE. Light or lavender-blue.

SUMMER NIGHT. Early purple.

SOUV. DE MONACO. Best crimson, late.

AMERICAN BEAUTY. Deep rose, tends to come blind under glass.

*QUEEN ALEXANDRA. Rosy lilac, fine.

BEAUTY OF NICE MIXED. All colors.

\section{GIANT EXCELSIOR (Column Type)}

We have a special strain of this type of our own production that we hope to have seed of for sale this fall.

\section{TEN WEEKS STOCKS}

This class is of compact branching habit, ideally suited for pot plants or bedding, but not for cut flowers. Produces a high percentage of doubles.

BLOOD RED.

CANARY YELLOW.

CARMINE PINK. LAVENDER.

PURPLE.

WHITE.

DEEP ROSE.

TEN WEEKS MIXED. All colors.

Prices on all the named or separate colors in the PERPETUAL, NICE $1 / 3 \mathrm{oz} .1 / 4 \mathrm{oz} .1 / 2 \mathrm{oz} .1 \mathrm{oz} .2 \mathrm{oz}$

and TEN WEEKS group..._...........

Perpetual, Nice or Ten Weeks in mixture..

$\begin{array}{lllll}.35 & .60 & 1.10 & 2.00 & 3.75\end{array}$

NOTE: Bismarcks are priced separately; see above. 



\section{The BALL CALENDULA "Standard of the World"!}

THE most valuable and easily grown

1 midwinter crop is Ball Calendula. If sown August 1 and grown in a night temperature of $45^{\circ}$ they will be in full crop for Christmas and January - the season of highest flower values. They are most economical to grow, doing best in a low temperature and, unlike bulb crops, the cost of seed is an insignificant item, about a dollar for a hundredfoot bench, even when the best grade of seed is used! From deep, glowing orange, through several shades of golden yellow and apricot, down to almost pure white, Ball Calendula furnish midwinter colors that cannot be had in any other class of flowers.

As originators of the Ball Calendula we are as careful as we can be to maintain and improve the original high quality of our stock.

We supply suggestions in detail for the growing of Ball Calendula both for the retail and the market grower. The grower who retails will be interested in a circular by Fritz Bahr. This is the most valuable contribution that has been made to the growing of this crop. Though you are an experienced grower, it might have valuable suggestions for you. The market grower will be interested in our own new and revised circular on the growing of this crop for the wholesale market. We gladly enclose either or both circulars on request.

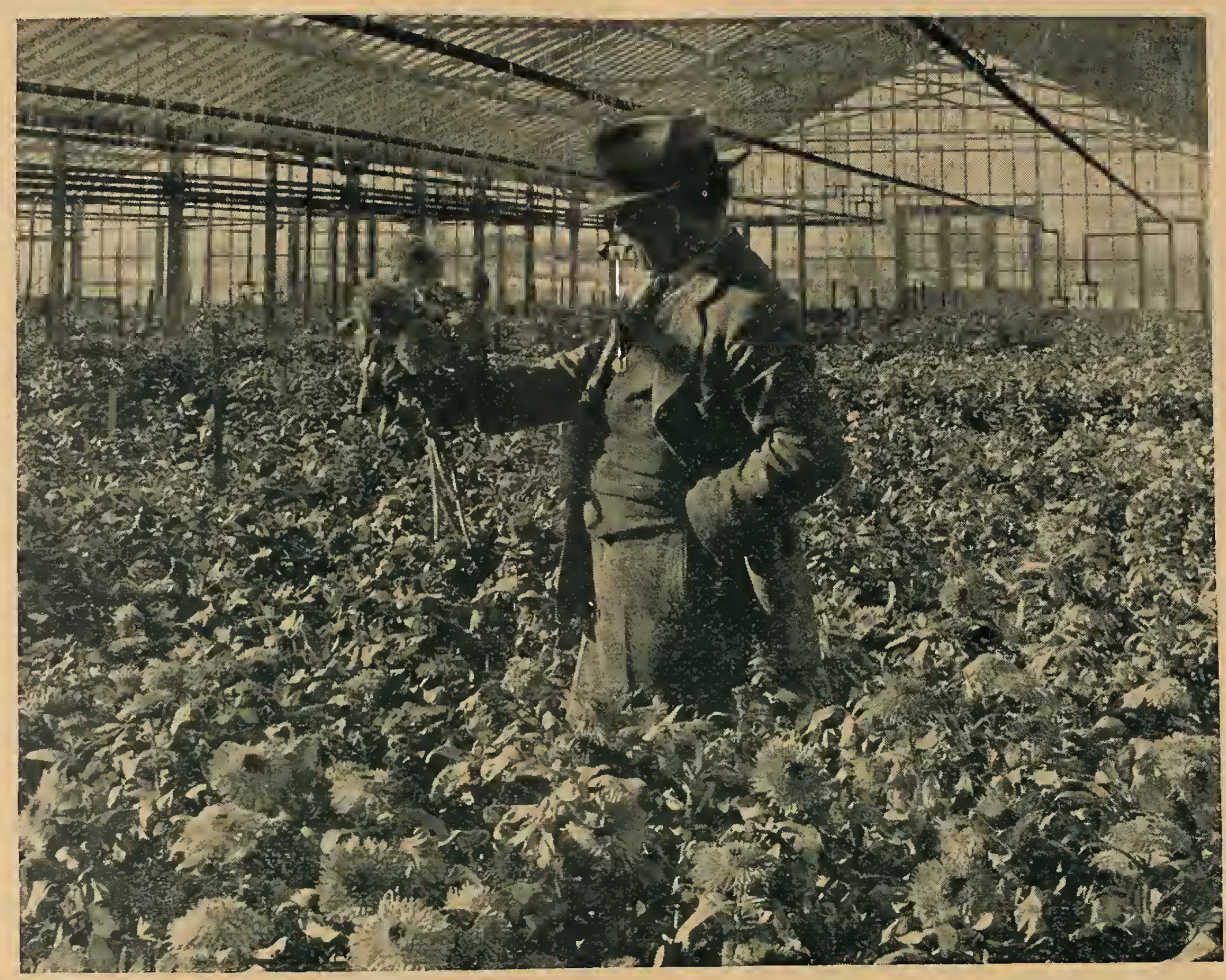

A house of our new dark centered yellow Ball's Lemon Queen.

\section{ABOUT VARIETIES}

The cut flower demand continues to center largely on the orange color, but to stimulate interest the various fother colors should be used. The lighter orange "Supreme" is used exclusively by some growers. Its contrasting dark center and freer-flower ph habit give it distinct value. Our "Gold" is the longest-stemmed and largest-flowering variety we have, and in large markets the demand for it is strong. Our "Apricot" adds a distinct touch of variety, so necessary in all lines of merchandise and surely flowers are not excepted.
BALL'S LEMON QUEEN. This is a clear, bright yellow with a dark center and of the true, long-stemmed Ball Calendula growth and size. It is without the heavy yellow effect of our Ball's Gold, being several shades lighter. This coloring, with its richly contrasting dark eye, makes Ball's Lemon Queen a distinctly valuable addition to our Ball Calendula family. extra long-stemmed selection from our regular orange. Large flower and strong grower. BALL'S ORANGE. Produces large, deep, full flowers. Of more compact growth beds the stems will be amply long. Calendula growth with long stems and large, BALL'S GOLD. Deep golden yellow. An extra large flower on an extra long stem. An extra large flower on an extra long stem. long stem, this variety is supremely. fine. BALL'S APRICOT. Rich straw or apricot color with a dark center. Not so longstemmed nor large as our Orange or Cold but freely produced, and a most attractive color. BALL'S WHITE. An attractive creamy white with a dark center. This is a shade lighter than our Apricot, which it resembles in size; not extra long-stenmed.

RADIO. "This is not a Ball type of calendula and is too short-stemmed for cut flower purposes. The slightly quilled effect of the petals adds an attractive effect to wide-open bedding.

Prices on all the above Ball Calendula and Radio: Trade Packet, 50c; $1 / 4$ oz., $\$ 1.00 ; 1 / 2$ oz., $\$ 1.75 ; 1$ oz., $\$ 3.00$; 2 oz., $\$ 5.00$. 4 oz. of any, or total order of $4 \mathrm{oz}$, $\$ 8.50$. $1 \mathrm{lb}$., $\$ 32.00$.

BALL CALENDULA MIXTURE.

For the retail grower whose planting is limited and who wishes some of all colors in Ball Calendula, we have prepared a mixture of the above, excepting Radio; this mixture is proportioned according to the cut flower value of the colors and includes about one-half orange. Priced as follows: Trade Packet, 40c; 1/4 oz., $75 \mathrm{c} ; 1 / 2$ Oz., $\$ 1.25 ; 1$ oz., $\$ 2.00$.
LEMON QUEEN. We have a finely selected stock of this light or lemon-yellow. Trade packet, $25 \mathrm{c} ; 1 / 2$ oz., $50 \mathrm{c} ; 1 \mathrm{oz}$.,
$\$ 1.00 ; 2$ oz... $\$ 1.50$. \$1.00; 2 oz.. \$1.50.
NANKEEN. Cream shaded apricot with light pink flush.
TRIANON. Apricot shaded yellow with a dark center. TRIANON. Apricot shaded yellow with a dark center.
Both Nankeen and Trianon are dwarf growers and suit-
able only for bedding. Priced at $1 / 4$ oz., 25c; 1 oz., 75c. 


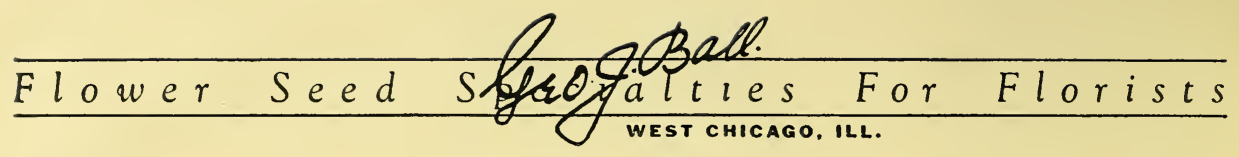

\section{The Best Winter Snapdragons}

ARLY-FLOWERING habit
and fine clear colors that come true to type are necessary points in winter-flowering snapdragons for Florists. Our own extensive trials, as well as the experience of others, clearly show the following varieties to be the finest available.

CEYLON COURT. The best early yellow.

CHEVIOT MAID. Fairly deep pink. The finest early in this color.

LAURA. Dark rose, with flowers well placed.

GENEVA PINK. A rich shade of soft rose-pink.

ROSE QUEEN (Witterstaetter). Described by the introducer as a large, early dark pink.

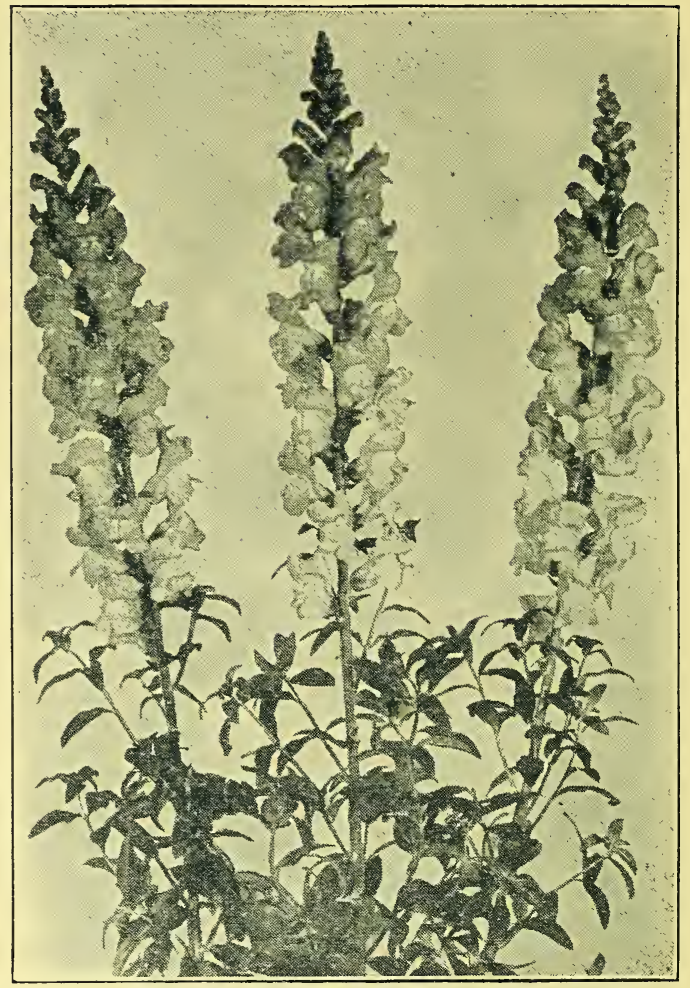

New Winter Blooming Snapdragon Rose Queen.

HAPPINESS (Allman). This is an attractive shade of rose-pink.

NOTE: While we have not grown the above two new varieties, from what we have seen of them we are certain they will rank with the finest cut flower snapdragons.

JENNIE SCHNEIDER. Beautiful shade of light rose-pink. Not extra early under our conditions.

HELEN. This is a beautiful shade of salmon. class.

AFTERGLOW. Deep golden bronze. The finest available in this color

IMP. SUNBURST. Color of Sunburst rose.

GOLDEN PINK QUEEN. Color as named.

WHITE ROCK. Standard long-stemmed white.

PURITY. Not so long-stemmed, but the pure white color is outstanding.

(For prices on above see next page) 


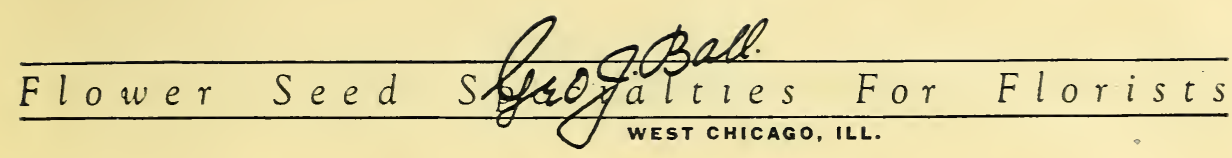

\section{PRICES ON THE BEST WINTER SNAPDRAGONS.}

\begin{tabular}{|c|c|c|c|c|}
\hline CEYLON COURT & $\$$ P1.00 & $\$ \$ 2.50$ & $\begin{array}{l}\text { 5 Pkts. } \\
\$ 4.00\end{array}$ & $\$ 5.50$ \\
\hline CHEVIOT MAID. & 1.50 & 4.45 & 7.35 & 10.00 \\
\hline LAURA & 1.50 & 4.00 & 6.25 & 8.50 \\
\hline GENEVA PINK & & 2.5 & 4.00 & 5.40 \\
\hline ROSE QUEEN (NEW) & & & & \\
\hline INESS & 2.00 & & & \\
\hline SCHNEID & 1.00 & & & 5.4 \\
\hline HEL & 1.00 & 2.50 & 3.75 & 5.50 \\
\hline & 2.00 & 5.0 & & 10.5 \\
\hline BURST & 1.50 & 4.0 & 6.25 & \\
\hline GOLDEN PINK QUEEN... & 1.00 & 2.50 & 3.75 & .4 \\
\hline WHITE POCK & & & & \\
\hline & .5 & 1.2 & 2.0 & \\
\hline ROMAN & 1.50 & 4.00 & 6.25 & \\
\hline
\end{tabular}

Many in the following list do exceptionally well and are popular with many growers:

MAJESTIC TWILIGHT. Extra large terra

1 Pkt. 3 Pkts. 5 Pkts. 7 Pkts. cotta yellow. Not extra early, fine for

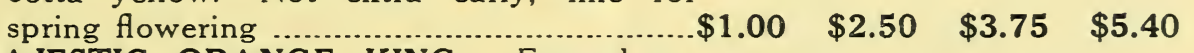

MAJESTIC ORANGE KING. Extra large orange. Fine for Spring flowering..............

ORLANDO. Standard bronze...................
PHILADELPHIA PINK. The standard pink..

SILVER PINK. Light pink...........................

MOHR'S PINK. Deep pink ........................... 1.50

$\begin{array}{llll}1.00 & 2.50 & 3.75 & 5.40\end{array}$

$\begin{array}{llll}1.00 & 2.50 & 3.75 & 5.40\end{array}$

$\begin{array}{llll}1.00 & 2.50 & 3.75 & 5.40\end{array}$

$\begin{array}{llll}1.00 & 2.50 & 3.75 & 5.40\end{array}$

NELROSE. Salmon-pink ..............1/4 oz., 75c .35

$4.00 \quad 6.25$

8.50

PENN ORANGE. Tangerine-orange.............. 1.00

$2.50 \quad 3.75$

5.40

JUDD'S DARK PINK.

1.00

2.50

3.75

JUDD'S LIGHT PINK.

1.00

2.50

5.40

5.40

GOLDEN QUEEN. A very good yellow.

3.75

$1 / 4$ oz.

CLIMAX. Bronze-orange; medium dwarf

1 Pkt.

$\$ 0.50$

$\$ 1.00$

.75

FAWN. Terra cotta yellow..............................................

GLORIA. Good pink; medium dwarf ................................ $\quad .35$

1.00

.75

HARMONY. Terra cotta pink........................................... . $\mathbf{. 3 5}$

ORCHID. Mauve-pink …...............................................

.75

.75

KEYSTONE. A good pink.

$1 / 8$ oz., $\$ 1.00 \quad .50$

The following are the choicest in the tall or MAXIMUM TYPE. They are extra large-flowered and long-stemmed. Their strong growth makes them entirely unsuited to winter forcing, but valuable for outdoor growing.

CANARY BIRD. Canary-yellow 1/4 oz. $1 \mathrm{Pkt}$.

CATTLEYA $\$ 0.60$ $\$ 0.35$

COPPER KING (INDIAN SUMMER

THE ROSE 


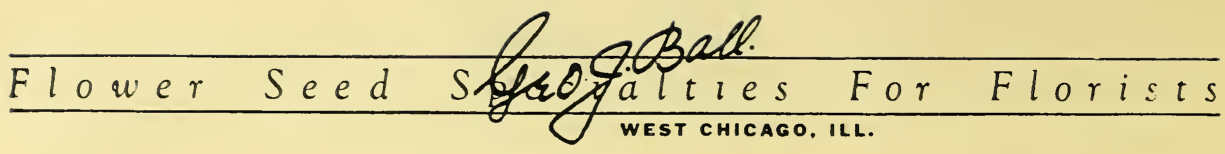

\section{Fine Pansies}

WE annually devote a 200 -foot bed to pansies for cutting and in this bed we line up a planting of everything we offer you as well as trials sent us from many specialists. We clearly note that the highly bred, large-flowered strains are not quite so free or early-flowering as are those of more medium size.

We are offering this season a selection of mixtures and separate colors that we believe quite covers the trade's requirements for both cut flowers and the sale of young plants.

SWISS GIANTS. Our trials clearly show this to be the preferred, all-purpose strain. Though not quite so early or free as Steele's Greenhouse Special, we find it decidedly larger and richer-colored. We, furthermore, find the texture of the flowers to be better than some other large-flowering strains, which means that they do not rot or spot so easily.

STEELE'S MASTERPIECE MIXED. A well named mixture of large flowers and richly colored.

STEELE'S MIRACLE MIXED. We find this to be a choice mixture of richly colored, long-stemmed flowers.

STEELE'S GREENHOUSE SPECIAL. We find this a very good longstemmed, all-purpose mixture and of special value to growers of market plants. Our stock is direct from the originator.

BALL'S GIANT MIXTURE. This is a special mixture intended for both cut flowers and plant sales. Contains a wide range of choice colors with a good proportion of the large-flowered types.

STEELE'S GOLDEN GATE YELLOW. A choice shade of yellow, originator's stock.

GOLDEN QUEEN. This is a very fine strain of pure, golden yellow.

LORD BEACONSFIELD. This is a combination of purple violet and blue and is the standard blue pansy.

\begin{tabular}{|c|c|c|c|c|c|c|}
\hline & Tr Pkt. & $1 / 8$ oz. & $1 / 4$ oz. & $1 / 2$ oz. & $1 \mathrm{oz}$ & $2 \mathrm{oz}$ \\
\hline STERPIECE & $\$ 1.00$ & $\$ 1.85$ & $\$ 3.50$ & $\$ 6.50$ & $\$ 12.00$ & \\
\hline STEELE'S MIRACLE MIXED.. & 1.00 & 1.5 & 2.75 & 5.00 & 9.00 & \\
\hline ELE'S GREENHOUSE SPECIAL & .75 & 1.0 & 1.7 & 3.2 & 6.00 & 11.00 \\
\hline MIXTURE & .50 & .80 & 1.50 & 2.75 & 5.00 & 9.00 \\
\hline ELE'S GOLDEN GATE YELLOW.. & 1.00 & 1.50 & 2.75 & 5.25 & 10.00 & \\
\hline DEN QUEEN & .25 & .3 & .50 & & & \\
\hline NSFIELD & .25 & .35 & .50 & 1.00 & 1.75 & 3.25 \\
\hline
\end{tabular}



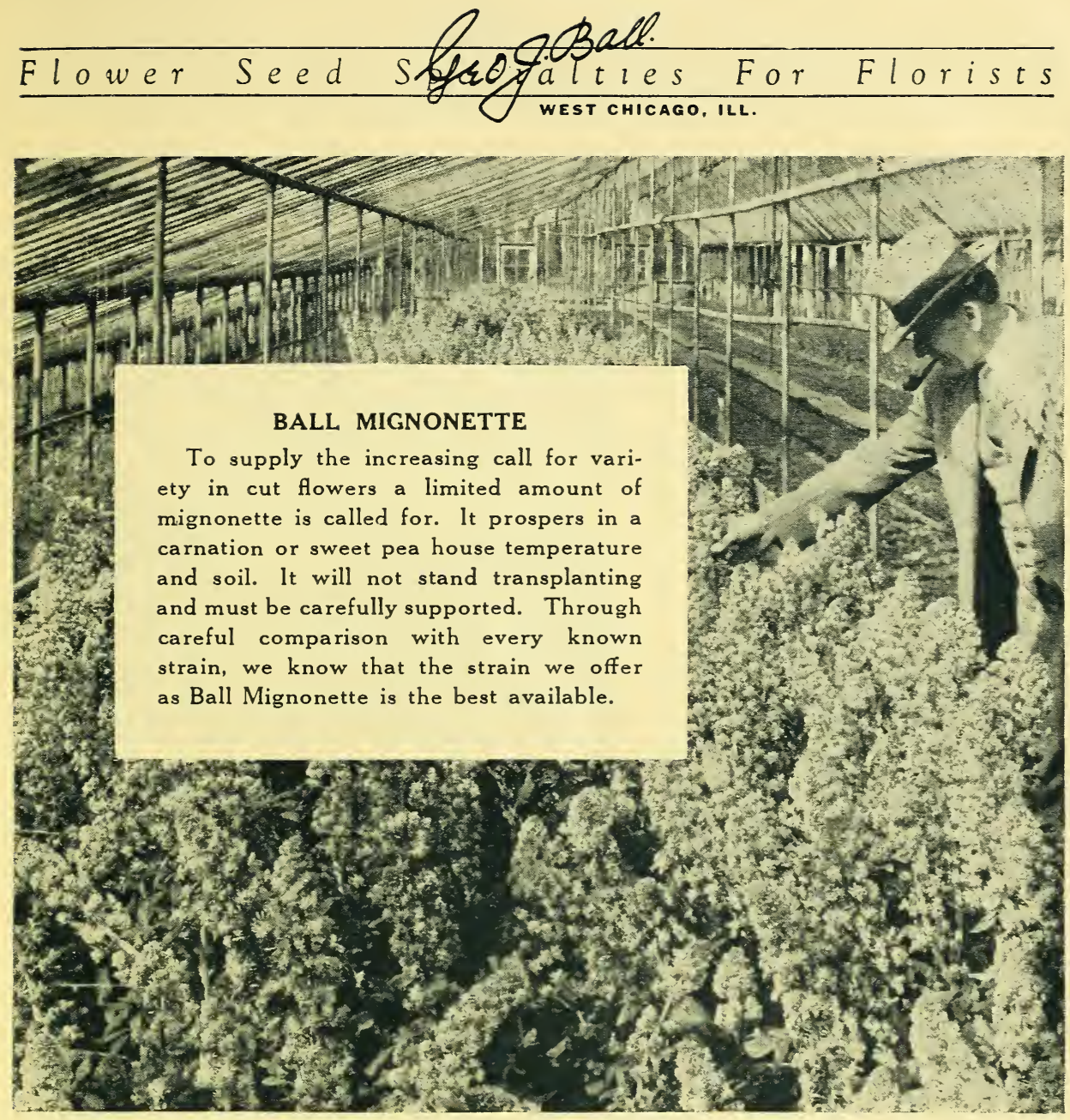

A bed of Ball Mignonette as grown by us at our Glen Ellyn greenhouses. Note the heavy, closely set long spikes. It is not only superior in this respect, but is a lighter and more attractive color and 2 to 3 weeks earlier than any other cut flower strain.

We also have a carefully selected stock of the well known New York Market strain.

Both Ball Mignonette and New York Market are priced as follows: Trade packet, $\$ 1.00 ; 1 / 4$ oz., $\$ 2.50 ; 1 / 20 z$, $\$ 4.00 ; 1$ oz., $\$ 7.00$.

\section{SCHIZANTHUS WISETONENSIS}

This is a valuable annual especially for the retail grower, and we know of nothing easier to handle. For Christmas flowering, sow seeds in September and shift on in pots, flowering in 4 -inch, and pinch back about November 1. For later flowering, shift in larger pots and keep pinched; in this way large specimens are produced for Spring flowering. They can also be sown out in a bed after Mums for Spring cut flowers. Must be grown in cool house.

\begin{tabular}{|c|c|c|}
\hline NDIFLORA “EXQUISITE MIXED”.......... & $\begin{array}{r}\text { Pkt. } \\
35 c\end{array}$ & $\begin{array}{c}1 / 4 \text { oz. } \\
50 c\end{array}$ \\
\hline GRANDIFLORA "ROSE and AMBER SHADES" & $35 c$ & 75c \\
\hline
\end{tabular}

MYOSOTIS BLUE BIRD We find this the most attractive in color and stem of all the strains of Forget-Me-Not. Tr. Pkt., 50c; $1 / 8$ oz., \$1.25. 


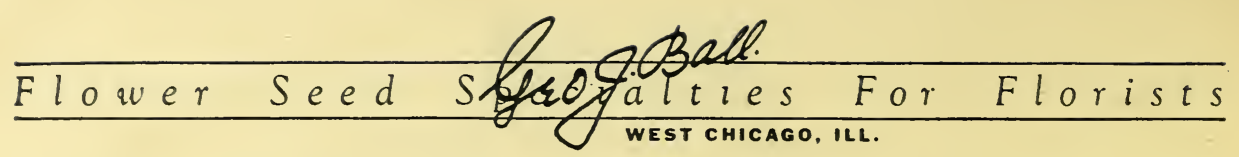

\section{Valuable Pot Plant Specialties from Seed}

FINE CINERARIAS.

No retail grower can afford to be without the showy cineraria. They must be closely watched throughout their growth for uniform moisture, greenfly and repotting and light shade during summer. A night temperature of $45^{\circ}$ will bring in a July 1 sowing for Christmas, but a sowing August 1 will produce fine midwinter specimens, and for Easter sow in September.

GIANT EXHIBITION MIXED. This stock is of dwarf, compact growth with flowers 4 to 5 inches across. Includes most attractive assortment of colors-blue and white shades, purple, carmine, crimson and red. This is the finest strain we are familiar with. Trade Packet, \$1.00; $1 / 64$ oz., \$2.50.

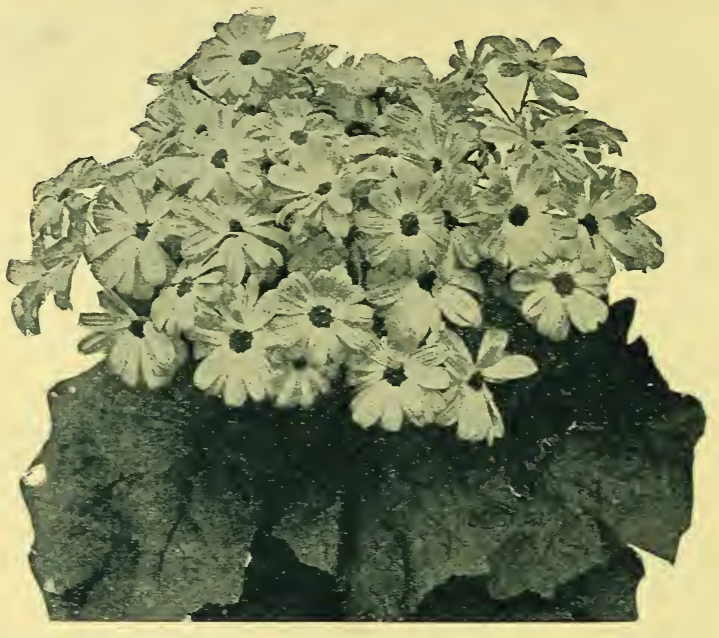

HYBRIDA GRANDIFLORA. A large-flowering strain of compact growth. While not so large as our Giant Exhibition, this is a choice strain that produces a rich assortment of colors. Trade Packet, 50c; $1 / 64$ oz., $\$ 1.50$.

MULTIFLORA NANA. Of dwarf, compact growth that covers itself with a mass of small showy blooms in wide range of brilliant colors. Trade Packet, 50c; $1 / 64$ oz., \$1.50.

CALCEOLARIAS. Among the very choicest pot plants that any careful grower can do to perfection in any old greenhouse are the calceolarias. Their show value is not fully appreciated. Sow in July and give same treatment that you do cinerarias.

EXTRA CHOICE MIXED. This mixture is made up of the choicest available colors of the marbled, spotted and variegated varieties. Trade Packet, $\$ 1.00 ; 1 / 64$ oz., $\$ 2.00$.

PRIMULA MALACOIDES (IMP. BABY PRIMROSE). This is the popular, light lilac primrose so largely grown as a winter pot plant. Sowing made in July and carried along in a $50^{\circ}$ house will grow into fine plants by midwinter and later. We have a fine strain of the standard light lilac color. Trade Packet, 50c; $1 / 16$ oz., $\$ 1.00$.

PRIMULA MALACOIDES ROSEA SUPERBA. A rich, fairly deep rose-colored type of Malacoides. This is a stronger color and by many growers considered the most attractive. Trade Packet, 50c; $1 / 16$ oz., \$1.50.

NEW DIANTHUS SWEET WIVELSFIELD. This is a new and enlarged type of Sweet William, originated and sold by an English grower. We can supply originator's seed. 100 seeds, $\$ 1.30 ; 1000$ seeds, $\$ 12.00$.

\section{AQUILEGIA.}

The many uses to which this hardy perennial can be put are not generally appreciated. For the retail grower they are fine for outdoor cutting. They can be forced in a cool house either for cutting or as pot plants, and your customers will buy them for outdoor planting. The varieties we offer cover the best to be had for these purposes.

SCOTT ELLIOTT HYBRIDS. This is a long-spurred type and is the choicest strain available. The colors range through shades of cream, yellow, pink, red, lavender, blue, etc. Trade Packet, 50c; $1 / 4$ oz., $\$ 1.50 ; 1$ oz., $\$ 5.00$.

DOBBIE'S IMPERIAL HYBRIDS. A very choice long-spurred strain from Europe considered by some as the finest. Trade Packet, 50c; $1 / 8$ oz., $\$ 1.00$.

JAETSCHAUI. Large yellow with red spurs; very choice.

Trade Packet, 50 c; $1 / 4$ oz., $\$ 1.00 ; 1$ oz., $\$ 3.50$.

CHOICE MIXED. This is a very good mixture of long-spurred mixed colors.

Trade Packet, 35 c; $1 / 4$ oz., $75 c ; 1$ oz., $\$ 2.00$. 


\section{Flower seed Steagohalties For Florists}

\section{Specialties for Summer Sowing}

\section{ASPARAGUS PLUMOSUS.}

We have a fine stock of lath house-grown, carefully harvested seed of this important specialty. 1000 seeds, $\$ 1.50 ; 10,000$ seeds, $\$ 12.00 ; 1 \mathrm{lb}$., $\$ 9.00$.

\section{ASPARAGUS SPRENGERI.}

100 seeds, $25 \mathrm{c} ; 1000$ seeds, $\$ 1.25 ; 1$ lb., $\$ 9.00$.

\section{CANDYTUFT.}

The Giant Hracinth and the Umbellata type are a distinctly valuable crop to follow mums and can be planted throughout the winter and outdoors in the spring. Our strain of Giant Hyacinth type is particularly fine.

\section{GIANT HYACINTH-FLOWERED}

Tr. Pkt. 1 oz. 4 oz. Select stock $\$ 0.25 \$ 0.80 \quad \$ 2.25$ UMBELLATA TYPE:

Rose Cardinal
Carmine ...
Lavender
White
Lilac
Flesh Pink
Crimson
Mixed

$\begin{array}{lll}.25 & .75 & 1.75 \\ .25 & .40 & 1.25 \\ .25 & .50 & 1.50 \\ .25 & .40 & 1.25 \\ .25 & .40 & 1.25 \\ .25 & .40 & 1.25 \\ .25 & .40 & 1.25 \\ .20 & .35 & 1.00\end{array}$

\section{CENTAUREA.}

There are some popular cut flowers under this heading. They are valuable for both outdoors and under glass, particularly the double Cyanus or Cornflower. The best color is blue. Rose is also a good color.

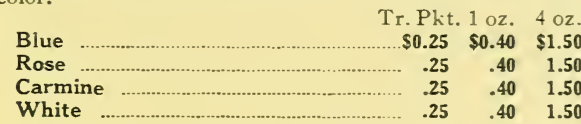

Centaurea Imperialis is the thistle type and is known as Sweet Sultan.

\begin{tabular}{|c|c|c|c|}
\hline & & & \\
\hline Amaranth Red & $\$ 0.30$ & $\$ 1.00$ & $\$ 3.50$ \\
\hline Brilliant Rose .. & .25 & .75 & 2.75 \\
\hline Deep Lavender & .25 & .75 & 2.75 \\
\hline icate Lilac. & .25 & .75 & 2.75 \\
\hline & .25 & .75 & 2.75 \\
\hline White & .25 & .75 & 2.75 \\
\hline ixed & .20 & .60 & 2.25 \\
\hline Suaveolens. (Yellow Sweet Sultan) & .20 & .45 & 1.75 \\
\hline Americana. (Large thistle type)... & .15 & .50 & 1.75 \\
\hline mericana Alba & .20 & .60 & 2.00 \\
\hline
\end{tabular}

\section{CYNOGLOSSUM AMABILE.}

(Chinese Forget-me not).

Grows 18 to 20 inches tall, with flowers of a true Forget-me-not blue. Of cut flower value. Trade Packet, 25c; 1 oz., $\$ 1.00$.

\section{DIDISCUS. (Cærulea).}

Long-stemmed, soft, lavender-colored flowers. Valuable novelty and easily grown. Trade Packet, $25 \mathrm{c} ; 1$ oz., $\$ 1.20 ; 4$ oz., $\$ 4.50$.

\section{DRAC ENA INDIVISA.}

Popular for vases and bedding. Trade Packet, 15c; 1 oz., 40c; 1 lb., $\$ 4.00$; 5 lbs., \$18.00.

\section{GERBERA JAMESONII.}

Grown in a night temperature of $55^{\circ}$ in well drained ground beds of rather light or sandy soil, this is a valuable cut flower crop with a real future. Our seed supply of this is grown for us under our personal supervision by a specialist, and we know that a better strain of assorted colors cannot be had. 100 seeds, $60 \mathrm{c} ; 1000$ seeds, $\$ 4.00$.

\section{GYPSOPHILA ELEGANS.}

\section{(Paris Market)}

Our stock of this is the true, large-flowering, pure white type that is so largely grown and used with cut flowers. Priced at: 1 oz., 25c; 4 oz., $75 \mathrm{c} ; 1$ lb., $\$ 1.50 ; 5$ lbs., $\$ 5.00$.

\section{LARKSPUR, ANNUAL.}

For planting after mums and throughout the winter, this annual is becoming increasingly. popular. Also valuable for outdoor cut flowers. Of the two distinct classes the stocks-flowered branching type is generally preferred. The hyacinth-flowered type, one tine long spike, is one to two weeks earlier, and, when well grown, is distinctly valuable. The pink shades are especially fine in both classes. Dark blue and lilac are also choice colors

\section{STOCKS-FLOWERED:}

Tr. Pkt. $1 / 4$ oz. $1 \mathrm{oz}$.

Exquisite Pink Imp. Finest............\$0.50 \$0.75 $\$ 2.00$

La France. Similar to above............ $\quad .50 \quad .75 \quad 2.00$

Empress Rose. Salmon-pink; fine.. $\quad .50 \quad .75 \quad 2.00$

Newport Pink. Deep pink ……….... $.25 \quad .75$

Dark Blue $\quad 25 \ldots$

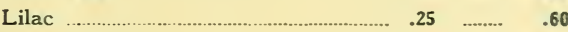

Rosy Scarlet ……….............................

Sky Blue $\quad .25 \quad .60$

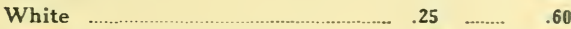

Mixed. Very choice mixture ........... $\quad .20 \quad$....... $\quad .50$

HYACINTH-FLOWERED :

Pink. Very fine............................. $.25 \quad .90$

Dark Blue ……...... .90

Lilac $\quad .25 \quad \ldots \ldots \ldots$

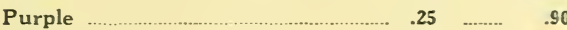

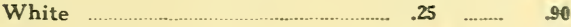

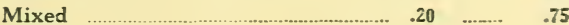

LUPINES, ANNUAL. (Hartwegii).

This is a raluable cut flower specialty. We find it most profitable to sow in August and carry along in 3 -inch pots to follow mums. They are much inclined to rot unless grown in fresh, clean soil and carefully watered. This is one of our specialties and our stoch of this is specially selected for us.

Dark Blue. Best color.

Sky Blue. Second best.

Rose.

White.

Priced at: Trade Packet, 15c; 1 oz., 30c; 4 oz., $\$ 1.00 ; 1 \mathrm{lb} ., \$ 3.00$

MIXED. Packet, 15c; 1 oz., 25c; 4 oz., 90c.

\section{SMILAX.}

Produces fine material for greens. Trade Packet, 25c; 1 oz., 50c; 4 oz., $\$ 1.75 ; 1$ lb., $\$ 6.00$. 


\section{Flower seed Slgegogalities For Florists}

\section{Hardy Perennial Specialties}

AQUILEGIA. See page 14.

CARNATION CHABAUD'S GIANT IMPROVED.

This hardy type of carnation has been greatly improved and will be found distinctly valuable as an outdoor cut flower. It will flower in five months from sowing, and, where climatic conditions are not too severe, it is hardy. Will come about $90 \%$ double. We offer the following choice colors: Cardinal Red,

Deep Rose, Flesh Pink and Rose Pink.

Trade Packet, 25c; $1 / 4$ oz., 60c; 1 oz., $\$ 2.00$.

SHASTA DAISY ALASKA. Extra large-flowered California type.

Trade Packet, 25c; $1 / 4$ oz., 75c; 1 oz., $\$ 2.00$.

DAISY, ELDER. This is from the Hartje \& Elder stock; comes quite true from seed.

Trade Packet, 35c; 1 oz., \$1.50.

DELPHINIUM.

Belladonna Imp. A decided improvement over the ordinary stock. This is the

finest strain of light blue Belladonna available.

Trade Packet, 50 c; $1 / 4$ oz., $\$ 1.00 ; 1$ oz., $\$ 3.00$.

Belladonna-Regular Stock.

Trade Packet, 50 c; $1 / 4$ oz., 85 c; 1 oz., $\$ 2.50$.

Bellamosum. Rich dark blue.

Trade Packet, 50 c; $1 / 4$ oz., 85 c; 1 oz. $\$ 2.50$.

Gold Medal Hybrids. This is a very good strain of assorted colors.

Trade Packet, 25c; $1 / 4$ oz., 75 c; 1 oz., $\$ 2.00$.

Wrexham Strain (Hollyhock Delphinium). We have never had the pleasure of growing a finer strain than this one. The colors range from light to dark blue with shadings of rose. Some spikes are very tall and tapering, while the flowering period extends from early to late.

Trade Packet, $\$ 1.00 ; 1 / 4$ oz., $\$ 2.00 ; 1$ oz., $\$ 6.00$.

GAILLARDIA. Perfectly hardy and valuable for cutting.

Portola Hybrids. The finest strain available.

Trade Packet, 50 c; $1 / 4$ oz., 75c; 1 oz., $\$ 2.00$.

Dazzler. A very good strain.

Trade Packet, 25c; $1 / 4$ oz., 50c; 1 oz., $\$ 1.50$.

GYPSOPHILA PANICULATA FL. PL. Perfectly hardy on well drained soil. The stock we offer will produce $30 \%$ to $40 \%$ double flowers.

Trade Packet, 50c; $1 / 8$ oz., $\$ 1.00 ; 1 / 4$ oz., $\$ 1.75 ; 1 / 2$ oz., $\$ 3.00 ; 1$ oz., $\$ 5.50$.

PYRETHRUM HYBRIDUM.

Grandiflora. Perfectly hardy and in full crop during June. Single mixed.

Trade Packet, 25 c; $1 / 4$ oz., 50c; 1 oz., $\$ 1.50$.

Double Mixed. About $40 \%$ of this strain will come semi-double; the balance

will be choice assorted shades. We find this the preferred stock for cut flowers.

Trade Packet, 50c; $1 / 8$ oz., $\$ 1.25 ; 1 / 4$ oz., $\$ 2.25 ; 1$ oz., $\$ 8.00$.

SCABIOSA.

Caucasica House Hybrids. This is a considerably improved strain in size and colors that range from azure-blue to silvery white.

Trade Packet, 75 ; $1 / 4$ oz., $\$ 1.25 ; 1$ oz., $\$ 4.00$.

Caucasica Lilac. A fine, clear lilac-lavender. Perfectly hardy perennial with a real cut flower value.

Trade Packet, 50 c; $1 / 4$ oz., 75 c; 1 oz., $\$ 2.00$.

Columbaria. A deep rosy mauve or pink. A valuable color for cut flowers.

Trade Packet, $50 \mathrm{c} ; 1 / 4$ oz., $\$ 1.00 ; 1$ oz., $\$ 3.00$.

STATICE LATIFOLIA. A valuable perennial that every retail florist should have a supply of. Can be cut and dried for winter use. Perfectly hardy. Light blue.

Trade Packet, 25 c; $1 / 4$ oz., 50 c; 1 oz., $\$ 1.50$.

COREOPSIS. Lanceolata. Fine for cutting. Trade Packet, 25c; 1 oz., 40c.

Double. A semi-double form. Trade Packet, 25c; 1 oz., \$1.00. 


\section{Profitable Petunias}

EOR some years past petunias have been so greatly improved that the supply of good plants is sold out with most growers well before the season is over. This clearly proves their increasing demand and appreciation. Considering the good margin of profit, retail growers should give special attention to this crop.

While much petunia seed is sown in January and later, the choice large-flowering $\mathrm{k}$ in $\mathrm{d}$ and es pe cially the double strains should be sown in December, and earlier in the south.

We fully realize our responsibility in being depended on for good seed as well as the choicest new varieties and strains in petunias and other flower seed specialties.

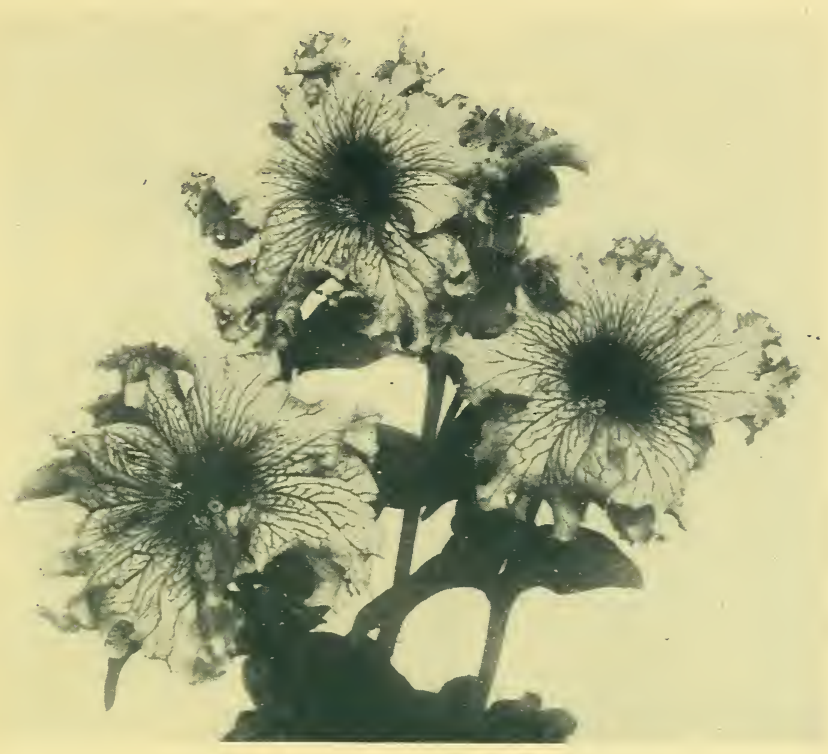

California Giant Petunias.
SINGLE SMALL-FLOWERED. This group is somewhat irregular in growth, with rather small flowers that are early and freely produced. Largely used for bedding.

General Dodds. Blood-red............... $\$ 0.25 \quad \$ 0.40 \quad \$ 1.50$

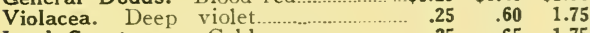

$\begin{array}{lllll} & .25 & .65 & 1.75\end{array}$

Howard's Star Imp. Purple, white

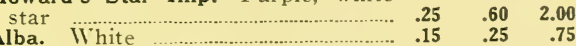

Alba. White

$25 \quad 40 \quad 1.00$

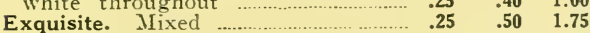

SINGLE SMALL-FLOWERED-DWARF (NANA

ERECTA). This class is of dwarf, compact habit, freeflowering and ideal for bedding.

$\begin{array}{llllll}\text { Violacea. } & \$ 0.25 & \$ 0.75 & \$ 2.50\end{array}$

$\begin{array}{lllll}\text { Rose of Heaven. Rose-pink } & .25 & .75 & 2.00\end{array}$

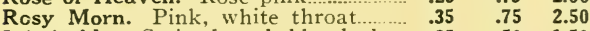

Inimitable. Striped and blotched.......

Snowball. Clear white....................... $\quad .25 \quad .50 \quad 1.50$

Heavenly Blue. Clear, silvery light

blue.................................. oz., \$1.00

BALCONY TYPE. So called because of their trailing or drooping habit. Ideal for porch or window boxes.

Balcony Queen …………………....... $\$ 0.50$

Tr. Pkt. $\frac{1}{16} \mathrm{Oz} \cdot 1 / 4 \mathrm{oz}$.

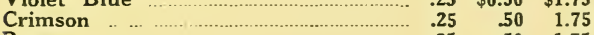

Rose ...

White

$\begin{array}{lll}.25 & .50 & 1.75\end{array}$

All the Best Mixed $\quad .25 \quad .50 \quad 1.75$

PORTLAND PETUNIAS. A very choice group for either bedding or pot plants. Elk's Pride is the richest, velvety violet to be found in petunias.

Tr.Pkt. $\frac{1}{32} \mathrm{Oz}$. $\frac{1}{16} \mathrm{Oz}$.

Elk's Pride. Dark purple, plain edge. \$0.50 $\$ 1.25 \quad \$ 2.25$

White Beauty. A vigorous-growing

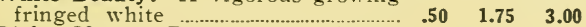

Pink Glory. Deep rose, slightly

fringed

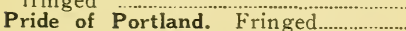

$\begin{array}{lll}.50 & 2.50 & 4.50\end{array}$

GIANTS OF CALIFORNIA. This is a very largeflowered, richly colored mixture of fine petunias. Largely used for either bedding or pots. The dwar strain is ideal for pot plants. The "Ramona" strain is select stock of dwarf California Giants and it makes fine pot plants.

Ramona Strain Tr. Pkt. $\frac{1}{32} \mathrm{Oz} \cdot \frac{1}{16} \mathrm{Oz} \cdot 1 / 8 \mathrm{oz}$

$\begin{array}{lllll} & \$ 1.00 & \$ 4.00 & \$ 7.00 & \$ 12.00\end{array}$ \begin{tabular}{lllll}
\hline & .50 & 1.75 & 2.75 & 5.00
\end{tabular} GIANT-FLOWERED SINGLE FRINGED. This class includes most of our finest large-flowered fringed varieties. They are effectively used as bedding plants and make ideal pot plants for Mothers day and Memorial day.

Theodosia. Very large fringed

Tr. Pkt. $\frac{7}{64} \mathrm{Oz} \cdot \frac{1}{32} \mathrm{Oz} \cdot \frac{1}{16} \mathrm{Oz}$ pink with light throat $\quad \$ 1.00 \quad \$ 2.00 \quad \$ 3.75$

Pink Triumph. Large, deepcolored, fringed rose..................

Fluffy Ruffles. Giant single fringed, mixed ....................................

Romany Lass. Crimson ………. $\quad .50 \quad 5$ for $\$ 2.00$

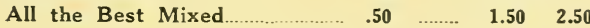

GIANT DOUBLE FRINGED. We offer the finest strain of this that can be had. It will average about $25 \%$ very choice doubles and about $15 \%$ more that will be fairly good. This stock produces little seed and must be hand-pollinated. For these reasons it is costly. The choicest plants, when in flower, should be selected for propagating by cuttings. Fine stocks are worked up in this way. The weakest seedlings are most inclined to come double.

Giant Double Fringed. Mixed colors. Trade Packet, $\$ 1.00 ; \frac{1}{6} \div$ oz., $\$ 8.00$.

DIENER'S GIANT RUFFLED MONSTERS. Half dwarf, large and ruffled.

Ruffled Blue and White Tr. Pkt. $\frac{1}{32}$ oz. $\frac{1}{15}$ oz. $1 / 80 z$

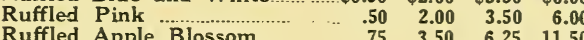
$\$ \begin{array}{llll}\$ 0.50 & \$ 2.00 & \$ 3.50 & \$ 6.00\end{array}$

Ruffled Monsters, Mixed $\quad \begin{array}{rrrrr}75 & 3.50 & 6.25 & 11.50\end{array}$ 
